\title{
International Law and the Pre-emptive Use of Force: Afghanistan, Al-Qaida, and Iraq
}

\author{
CHRISTOPHER GREENWOOD*
}

\section{TABLE OF CONTENTS,}

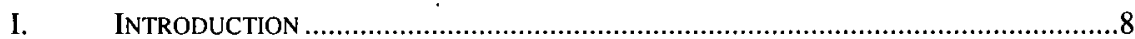

II. THE LEGAL FRAMEWORK OF THE USE OF FORCE

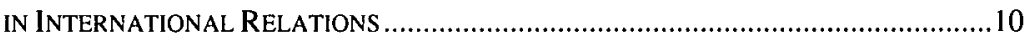

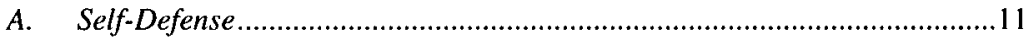

1. Self-Defense Against Threatened Attacks ........................................12

2. Self-Defense Against Threats from Terrorists ...................................16

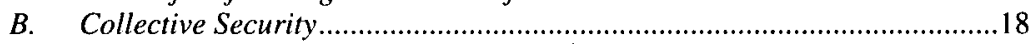

1. Collective Security and Pre-emptive Action .....................................19

2. Collective Security and Terrorism.....................................................19

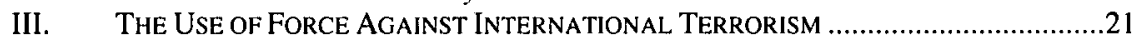

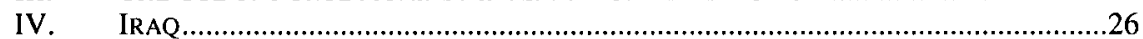

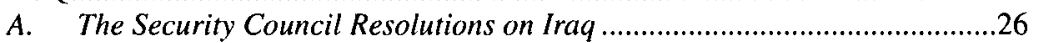

B. The Legality of Military Action Against Iraq .............................................33

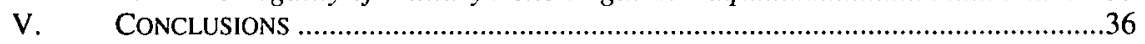

* CMG, QC; Professor of International Law, London School of Economics and Political Science. The author acknowledges with gratitude the assistance of Mr. Jonathan Drakeford, LLM, in checking references. He also wishes to express particular gratitude to the editorial team of the Journal in preparing this Article for the press and for the patience with which they bore the last minute changes necessitated by events in Iraq. 


\section{INTRODUCTION}

The question whether international law permits the use of force not in response to existing violence but to avert future attacks has taken on added significance in the aftermath of the events of September 11, 2001 and with the debate about Iraqi weaponry. Referring both to the threat of terrorist attack and the dangers posed by "rogue States", the National Security Strategy document, issued by President Bush in September 2002, warns:

The United States has long maintained the option of pre-emptive actions to counter a sufficient threat to our national security. The greater the threat, the greater is the risk of inaction-and the more compelling the case for taking anticipatory action to defend ourselves, even if uncertainty remains as to the time and place of the enemy's attack. To forestall or prevent such hostile acts by our adversaries, the United States will, if necessary, act pre-emptively.

The United States will not use force in all cases to pre-empt emerging threats, nor should nations use pre-emption as a pretext for aggression. Yet in an age where the enemies of civilization openly and actively seek the world's most destructive technologies, the United States cannot remain idle while dangers gather.

The purpose of our actions will always be to eliminate a specific threat to the United States or our allies and friends. The reason for our actions will be clear, the force measured, and the cause just.

Nor have such sentiments been confined to the U.S. administration. Members of the Australian government, for example, have called for a reconsideration of the U.N. Charter provisions on self-defense to permit greater latitude for pre-emptive action. ${ }^{2}$

To some commentators, such statements are symptomatic of a disturbing willingness on the part of certain governments to disregard international law; others see them as indications of the need for a fundamental reconsideration of that law-possibly even including an amendment of the U.N. Charter-to meet a wholly new type of threat. Before embracing either school of thought, however, it is appropriate to examine whether, and if so under what circumstances, existing international law permits the use of force to prevent an attack that has not yet materialized. To that end, Part II. of this Article will review the legal framework on the use of force and suggest that there are cases in

1. President George W. Bush, The National Security Strategy of the United States of America, 15-16 (Sept. 17, 2002), at http://www.whitehouse.gov/nsc/nss.pdf.

2. See, e.g., Senator Robert Hill, The John Bray Memorial Oration, 4, 6-8 (Nov. 28, 2002), available at http://www.minister.defence.gov.au/2002/694281102.doc (last visited Feb. 6, 2003); Doorstop Interview, 4-5 (Nov. 28, 2002), at http://www.minister.defence.gov.au/HillSpeechtpl.cfm?CurrentID=2120; see also Interview by Neil Mitchell with Prime Minister John Howard, 5-6 (Nov. 29, 2002), available at http://www.pm.gov.au/news/interviews/2002/interview2013.htm (last visited Feb. 6, 2003). 
which the use of "pre-emptive force" may be justified, provided that certain important conditions are satisfied. Parts III. and IV. will then apply this analysis to the two cases that have focused attention on the whole issue of pre-emptive action, namely, the threat from international terrorism (Part III.) and the situation in Iraq (Part IV.). The writer's conclusions are summarized in Part V.

At the outset, however, it is important to sound three notes of caution. First, there is no agreement regarding the use of terminology in this field. As a result, some commentators distinguish between "anticipatory" military action (which they generally use to describe military action against an imminent attack) and "pre-emptive" force (normally employed to describe the use of force against a threat that is more remote in time). Although this approach offers the appearance of precision, the appearance is deceptive because so many others use the two terms interchangeably. Statements about "pre-emptive" or "anticipatory" action need, therefore, to be treated with some caution. The present Article tries to avoid treating such words as though they were terms of art.

Secondly, publication deadlines meant that this Article was written at the end of January 2003, at the time that that the chief weapons inspector, Dr. Hans Blix, and the Director-General of the International Atomic Energy Agency, Dr. Mohammed El Baradei, made their first reports to the U.N. Security Council on the extent of Iraqi compliance with Security Council resolution 1441 (2002). ${ }^{3}$ The proofs of the Article were revised on March 22, 2003, three days after the United States, United Kingdom, and other States commenced military operations against Iraq. While it has been possible to take account in the text of some developments between late January and the outbreak of fighting in mid-March 2003, it has not been possible to discuss these developments in detail or to amend the footnotes to give full references to the relevant documentation. ${ }^{4}$

Finally, it is of course well-established that the use of force in international relations is lawful only if it satisfies two requirements. The recourse to force, and the degree of force employed, must be lawful under the legal regime codified in the U.N. Charter (the ius ad bellum).

3. U.N. SCOR, 58th Sess., 4692nd mtg., U.N. Doc. S/PV.4692 (2003), at http://odsdds-ny.un.org/doc/UNDOC/GEN/N03/224/61/PDF/N0322461.pdf?OpenElement [hereinafter U.N. Doc. S/PV.4692].

4. The United Kingdom Government Papers, IRAQ (Cm 5769, Feb. 2003); and IRAQ: UN DOCUMENTS OF EARLY MARCH 2003 (Cm 5785, Mar. 2003) contain invaluable collections of the later documents. 
In addition, the conduct of hostilities must meet the requirements of international humanitarian law (the ius in bello). ${ }^{5}$ Space, however, does not permit discussion of the ius in bello here and the present Article is therefore confined to ius ad bellum questions.

\title{
II. THE LEGAL FRAMEWORK OF THE USE OF FORCE IN INTERNATIONAL RELATIONS
}

There is broad agreement on the main principles that make up the international law on the use of force. The starting point is the Preamble to the U.N. Charter, which affirms that the "Peoples of the United Nations" are "determined to save succeeding generations from the scourge of war, which twice in our lifetime has brought untold sorrow to mankind", and Article 1(1), which gives, as the first purpose of the United Nations:

\begin{abstract}
To maintain international peace and security, and to that end: to take effective collective measures for the prevention and removal of threats to the peace, and for the suppression of acts of aggression or other breaches of the peace, and to bring about by peaceful means, and in conformity with the principles of justice and international law, adjustment or settlement of international disputes or situations which might lead to a breach of the peace.
\end{abstract}

These provisions make clear the importance, in the legal order embodied in the Charter, of maintaining international peace but also the readiness to use force to combat aggression and to prevent threats to the peace from materializing into acts of aggression or breaches of the peace-the Charter is about keeping the peace not about pacifism.

Article 2(4) then introduces into international law the most far-reaching limitation ever adopted on the use of force by States against one another:

All Members shall refrain in their international relations from the threat or use of force against the territorial integrity or political independence of any State, or in any other manner inconsistent with the Purposes of the United Nations.

This provision was an innovation in 1945 and is cast in terms of an obligation binding only upon Members of the United Nations, but it has long been recognized as stating a principle that has become part of customary international law and, indeed, a rule of ius cogens, binding all States. ${ }^{6}$ Although it has sometimes been suggested that it states only a partial prohibition and that some instances of recourse to force between States fall wholly outside its scope, ${ }^{7}$ this is very much a minority view and most States

5. See Christopher Greenwood, The Relationship of Ius ad Bellum and Ius in Bello, 9 REV. INT'L STUD. 221 (1983).

6. See, e.g., Military and Paramilitary Activities (Nicar. v. U.S.), 1986 I.C.J. 14, 99-100 (June 27).

7. See, e.g., Anthony D'Amato, Israel's Air Strike Upon the Iraqi Nuclear Reactor, 77 AM. J. INT'L L. 584 (1983). 
and commentators treat Article 2(4) as prohibiting all use of force by one State against another, or on the territory of another, unless that use of force is justified by one of the limited exceptions provided for in international law. ${ }^{8}$

The Charter expressly provides for two such exceptions: military action in self-defense, the right to which is preserved by Article 51, and military action taken or authorized by the U.N. Security Council under the collective security provisions of Chapter VII of the Charter. ${ }^{9}$

This section will focus on two questions. First, to what extent, if at all, does either the right of self-defense or the collective security powers of the Security Council permit military action to avert a threat that has not yet materialized in the form of actual violence? Secondly, do these powers permit a military reaction against threats emanating from terrorist groups or are they confined to threats from States?

\title{
A. Self-Defense
}

The right of self-defense is not created by the Charter-it is a customary law right of some antiquity and is said to be inherent in the concept of Statehood-but the conditions for its exercise are mostly to be found in the provisions of Article 51, which states that:

\begin{abstract}
Nothing in the present Charter shall impair the inherent right of individual or collective self-defense if an armed attack occurs against a Member of the United Nations, until the Security Council has taken measures necessary to maintain international peace and security. Measures taken by members in the exercise of this right of self-defense shall be immediately reported to the Security Council and shall not in any way affect the authority and responsibility of the Security Council under the present Charter to take at any time such action as it deems necessary to maintain or restore international peace and security.
\end{abstract}

The exercise of the right of self-defense is not subject to any requirement of prior authorization by the U.N. Security Council; it is an aspect of the sovereignty of the State (although subject to the limitations imposed by

8. See Bush, supra note 1, at 15; IAN BROWNLIE, INTERNATIONAL LAW AND THE USE OF ForCE BY STATES 112 (1963); D.W. BOWETT, SELF-DEFENCE IN INTERNATIONAL LAW 1 12-13 (1958); OSCAR SCHACHTER, INTERNATIONAL LAW IN THEORY AND PRACTICE 110 (1991). For discussion of these issues see also CHRISTINE GRAY, INTERNATIONAL LAW AND ThE USE OF ForCE (2000); Yoram DinSTEIN, WAR, Aggression and SELFDEFENCE (3rd ed., Cambridge Univ. Press 2001).

9. The present writer is one of those who asserts that there is also a right to take military action in extreme cases of humanitarian need, such as that which existed in Kosovo in 1999; see the writer's evidence to the House of Commons Foreign Affairs Committee, reproduced as Christopher Greenwood, International Law and the NATO Intervention in Kosovo, 49 INT'L \& CoMP. L.Q. 926 (2000). 
international law, as will be seen). Self-defense may be individual (in response to an armed attack upon the State exercising the right) or collective (where a State or group of States go to the assistance of a State that is the victim of an armed attack, even though they have not themselves been attacked and are not directly threatened). ${ }^{10}$

It is noteworthy that Article 51 preserved the "inherent right" of selfdefense, rather than creating a right, which otherwise would not have existed. Moreover, it was a comparatively late addition to the Charter, for most States initially assumed that "the right of self-defense was inherent in the proposals and did not need explicit mention in the Charter". "The customary law status of the right of self-defense and the close relationship between the customary principle and the provisions of Article 51 have been confirmed by the International Court and are not a matter of controversy. ${ }^{12}$ That provision does not, however, state all of the requirements for a lawful resort to force in self-defense, for it is generally agreed that, to be lawful, the use of force must not exceed what is necessary and proportionate in self-defense.

\section{Self-Defense Against Threatened Attacks}

Although Article 51 refers to the right of self-defense "if an armed attack occurs", the United Kingdom ${ }^{13}$ and the United States ${ }^{14}$ have consistently maintained that the right of self-defense also applies when an armed attack has not yet taken place but is imminent. This view of self-defense can be traced back to the famous Caroline incident of 1837. ${ }^{15}$ That incident involved action taken by U.K. forces in Canada against the Caroline, a merchant vessel that was being used by Canadian rebels and their American supporters in attacks against Canada. British forces attacked the Caroline while she was on the U.S. side of the Great Lakes and destroyed her, killing some members of her crew. One of the British officers involved, a Lieutenant McLeod, was subsequently arrested in the United States on charges of murder arising out of the incident. The British government maintained that its forces had acted in

\footnotetext{
10. For the limits of the right of collective self-defence see Military and Paramilitary (Nicar. v. U.S.), supra note 6, at 104-06.

11. United Kingdom Commentary on the United Nations Charter, Cmd. 6666, at 9.

12. Military and Paramilitary (Nicar. v. U.S.), supra note 6, at 102-03.

13. See, e.g., the statements by the U.K. government regarding the 1986 attack by the United States on Libya, 57 BRIT. Y.B. INT'L L. 494, 639-41 (1986).

14. See, e.g., the statements by the U.S. government at the time of its attack on Libya, Legal Regulation of Use of Force, 1980-88 DIGEST § 1 at 3405-06.

15. The correspondence between the two governments is set out in 2 J.B. MOORE, DiGEST OF INTERNATIONAL LAW 412-29 (1906); 29 B.F.S.P. $1137-38$; 30 B.F.S.P. 195-96. See also R.Y. Jennings, The Caroline and McLeod Cases, 32 AM. J. INT'L L. 82 (1938).
} 
exercise of the right of self-defense and demanded McLeod's release. Secretary of State Daniel Webster's reply has long been regarded as a definitive statement of the right of self-defense in international law. Webster recognized that the right of self-defense did not depend upon the United Kingdom having already been the subject of an attack but accepted that there was a right of anticipatory self-defense in the face of a threatened armed attack, provided that there was "a necessity of selfdefense, instant, overwhelming, leaving no choice of means and no moment for deliberation." 16 McLeod was subsequently released. The Caroline test was applied by the International Military Tribunals at Nuremberg ${ }^{17}$ and Tokyo. ${ }^{18}$ This suggests that a right of anticipatory selfdefense against imminent threats of armed attack was part of the customary law right preserved by Article 51 of the Charter.

Practice $^{19}$ since 1945 (though not always unequivocal by any means) tends to support that conclusion and confirms that the right of selfdefense in the Charter era continues to include a right to use force to avert imminent armed attack. The practice of the United Kingdom and the United States has already been mentioned. As Sir Derek Bowett has pointed out, even the Soviet Union, which was initially strongly opposed to any concept of anticipatory self-defense, itself relied on such a right at various times. $^{20}$ Two particularly revealing instances of State recognition of a right of anticipatory self-defense are the debates in the Security Council on the 1967 six-day war between Israel and the Arab States, as well as the 1981 Israeli attack on Iraq's nuclear reactor.

In the first case, although Israel's recourse to force against Egypt has sometimes (unconvincingly) been explained as a response to an actual attack or as the exercise of belligerent rights stemming from a war that

16. Letter from Daniel Webster to Henry S. Fox (Apr. 24, 1842), 29 BRIT. AND FOREIGN STATE PAPERS 1129, 1138 (1857), quoted in LORI DAMROSCH, INTERNATIONAL LAW: CASES AND MATERIALS 923 (2001).

17. 13 ANN. DIG. \& REP. PUB. INT'L L. CASES 203, 210; International Military Tribunal (Nuremberg), Judgment and Sentences, 41 AM. J. INT'L L. 172, 205 (1947); Cmd. 6964, at 28-30.

18. See International Military Tribunal at Tokyo (1948), in 2 THE LAW OF WAR: A DOCUMENTARY HISTORY 1029, 1157-59 (Leon Friedman ed., 1972).

19. There has been no conclusive statement by the International Court of Justice on this subject. See, e.g., Military and Paramilitary Activities (Nicar. v. U.S.), supra note 6, at 99-100 (noting that the question of anticipatory self-defense did not arise on the facts of the case and expressly left the matter open).

20. D.W. Bowett, The Use of Force for the Protection of Nationals Abroad, in THE CurRent Legal Regulation OF THE USE OF ForCE 39, 40, n.8 (Antonio Cassese ed., 1986). 
had not formally been terminated, as Professor Franck has indicated, Israel's "words and actions clearly asserted a right of anticipatory selfdefence against an imminent armed attack". 21 In Professor O'Brien's words, it was "a model case for anticipatory self-defense". 22 Moreover, the international reaction suggests that this claim struck a chord with other States. A Soviet draft resolution, which would have condemned Israel for an unlawful resort to force, achieved only four votes in the Security Council and was thus roundly defeated. ${ }^{23}$ In the General Assembly, a similar resolution was also voted down. ${ }^{24}$ The reaction of other States led Franck to conclude:

\begin{abstract}
[Israel's] attack on Egypt was in anticipation of an armed attack, not a reaction to it. Most States, on the basis of the evidence available to them, did however apparently conclude that such an armed attack was imminent, that Israel had reasonably surmised that it stood a better chance of survival if the attack were pre-empted, and that, therefore, in the circumstances, it had not acted unreasonably. This does not amount to an open-ended endorsement of a general right to anticipatory self-defence, but it does recognize that, in demonstrable circumstances of extreme necessity, anticipatory self-defence may be a legitimate exercise of a State's right to ensure its survival. ${ }^{25}$
\end{abstract}

Although international reaction to the 1981 Israeli attack on Iraq's nuclear reactor, on the other hand, was generally condemnatory of Israel, ${ }^{26}$ in most cases that reaction was based on a conclusion that Israel had failed to demonstrate that there was an imminent threat from Iraq and had thus failed to satisfy the Caroline requirements for anticipatory self-defense, rather than on any rejection of anticipatory self-defense as such. ${ }^{27}$ Indeed, the emphasis on this failure to demonstrate the existence of an imminent threat tends, if anything, to confirm the existence of a right of self-defense in cases where such an imminent threat was shown to exist.

Academic opinion on this question is divided. Brownlie, ${ }^{28} \mathrm{Gray},{ }^{29}$ and Henkin, ${ }^{30}$ among others, have argued that there is no right of selfdefense until an armed attack has actually commenced. Dinstein ${ }^{31}$ also

21. Thomas Franck, Recourse to Force 103 (2002); but see Gray, supra note 8 , at 112 .

22. William V. O'Brien, The Conduct of Just and Limited War 133 (1981).

23. 1967 U.N.Y.B. 190.

24. A/L.521 was rejected on July 4,1967 by seventy-one votes against to twentytwo in favor, with twenty-seven abstentions. G.A. Draft Res. A/L.521, U.N. GAOR. 5th Emergency Special Sess., U.N. Doc. A/6717 (1967). For vote verification see 1967 U.N.Y.B. 209, U.N. Sales No. E.68.I.1.

25. FRANCK, op. cit., supra note 21 , at 105.

26. See S.C. Res. 487, U.N. SCOR, 36th Sess., 2288th mtg., U.N. Doc. S/RES/487 (1981) (adopted unanimously, condemning the Israeli action).

27. FRANCK, op. cit., supra note 21, at 105-07.

28. BROWNLIE, supra note 8 , at 257-76.

29. GRAY, supra note 8, at 112 .

30. Louis HENKIN, HOW NaTIONS BeHAVE 141-44 (1979).

31. DinSTEIN, supra note 8 , at 182. 
rejects anticipatory self-defense but accepts that there is a right of "interceptive self-defense", where a State has "committed itself to an armed attack in an ostensibly irrevocable way", an approach that differs but little from that in the Caroline case. On the other hand, in addition to Franck (whose work has already been cited), Waldock, ${ }^{32}$ Fitzmaurice, ${ }^{33}$ Bowett, ${ }^{34}$ Schwebel, ${ }^{35}$ and Jennings and Watts ${ }^{36}$ have all argued that there is a right of anticipatory self-defense against an imminent armed attack. ${ }^{37}$ The position is, perhaps, best summed up by Judge Higgins, who said:

[I]n a nuclear age, common sense cannot require one to interpret an ambiguous provision in a text in a way that requires a state passively to accept its fate before it can defend itself. And, even in the face of conventional warfare, this would also seem the only realistic interpretation of the contemporary right of self-defence. It is the potentially devastating consequences of prohibiting selfdefence unless an armed attack has already occurred that leads one to prefer this interpretation-although it has to be said that, as a matter of simple construction of the words alone, another conclusion might be reached. 38

In the present writer's opinion, this view accords better with State practice and with the realities of modern military conditions than with the more restrictive interpretation of Article 51, which would confine the right of self-defense to cases in which an armed attack had already occurred.

Nevertheless, that practice also shows that the right of anticipatory self-defense is confined to instances where the armed attack is imminent. Not only was this limitation a central feature of the Caroline correspondence, it was the basis on which the Nuremberg Tribunal, while affirming the Caroline test, rejected the defense plea that the German invasion of Norway had been an act of anticipatory self-defense. It was also the basis for rejection of the Israeli claim in the reactor case. In so far as talk of a doctrine of "pre-emption" is intended to refer to a broader right of self-defense to respond to threats that might materialize at some time in the future, such a doctrine has no basis in law.

32. $81 \mathrm{RC}(1952-\mathrm{II})$ 496-98.

33. $92 \mathrm{RC}(1957-\mathrm{II}) 171$.

34. BOWETT, supra note 8 , at $187-92$.

35. $136 \mathrm{RC}(1972-\mathrm{II})$ 478-83.

36. 1 OPPENHEIM's INTERNATIONAL LAW 421 (Sir Robert Jennings and Sir Arthur Watts eds., 9th ed. 1992).

37. Waldock, Schwebel, and Jennings are all past Presidents of the International Court of Justice; Fitzmaurice was a Judge of that Court.

38. Rosalyn Higgins, Problems and Process: International law and How WE USE IT 242 (1994). 
In assessing what constitutes an imminent armed attack, however, it is necessary to take into account two factors that did not exist at the time of the Caroline incident. The first is the gravity of the threat. The threat posed by a nuclear weapon, or a biological or chemical weapon, if used against a city, is so horrific that it is in a different league from the threats posed (as in the Caroline) by cross-border raids conducted by men armed only with rifles. Where the threat is an attack by weapons of mass destruction, the risk imposed upon a State by waiting until that attack actually takes place compounded by the impossibility for that State to afford its population any effective protection once the attack has been launched, mean that such an attack can reasonably be treated as imminent in circumstances where an attack by conventional means would not be so regarded. The second consideration is the method of delivery of the threat. It is far more difficult to determine the time scale within which a threat of attack by terrorist means would materialize than it is with threats posed by, for example, regular armed forces. These would be material considerations in assessing whether, in any particular case, an attack should be treated as imminent.

Nevertheless, the requirement that the attack be imminent cannot be ignored or rendered meaningless. Even when taking into account the issues considered in the preceding paragraph, the right of self-defense will justify action only where there is sufficient evidence that the threat of attack exists. That will require evidence not only of the possession of weapons but also of an intention to use them.

\section{Self-Defense Against Threats from Terrorists}

In the aftermath of the events of September 11, 2001, it is also necessary to ask whether the concept of "armed attack" in Article 51 of the Charter is capable of including a terrorist attack. The concept of "armed attack" is, it is true, generally used with reference to the employment of regular armed forces by states. There is, however, no a priori reason why the term should be so confined. There is no doubt that terrorist acts by a state can constitute an armed attack and thereby justify a military response. ${ }^{39}$ The U.N. General Assembly included certain types of terrorist activity committed by States in its definition of aggression in $1974 .^{40}$ Similarly, the International Court of Justice, in its judgment in the Nicaragua case in 1986, considered that covert military

39. For a discussion of this issue see Christopher J. Greenwood, International Law and the United States' Air Operation Against Libya, 89 W. VA. L. REv. 933, 939-45 (1987) (discussing whether pre-emptive force against anticipated terrorist attacks is justifiable).

40. G.A. Res. 1334, U.N. GAOR, 29th Sess., Supp. No. 31, U.N. Doc. A/9631 (1974) [hereinafter G.A. Res. 1334]. Article 3 lists a series of acts that are to be considered as aggression and includes, in sub-paragraph $(\mathrm{g})$, "the sending by or on behalf of a state of armed bands, irregulars or mercenaries which carry out acts of armed force against another state of such gravity as to amount to the acts listed [earlier in the paragraph]." 
action by a state could be classified as an armed attack if it was of sufficient gravity. ${ }^{41}$ The level of violence employed on September 11, 2001 undoubtedly reached that level of gravity. There is, therefore, no doubt that had those attacks been the work of a state, rather than a terrorist organization like Al-Qaida, they would have been classified as an armed attack for the purposes of Article 51 and the right of self-defense. It would be a strange formalism that regarded the right to take military action against those who caused or threatened such actions as dependent upon whether or not their acts could be imputed to a state.

There is, however, no reason to think that international law adopts such a formalistic approach. On the contrary, the famous Caroline dispute, ${ }^{42}$ itself shows that an armed attack need not emanate from a state. The threat in the Caroline case came from a non-state group of the kind most would probably call terrorist today. The United States was not supporting the activities of that group and certainly could not be regarded as responsible for their acts. Yet, nowhere in the correspondence or in the subsequent reliance on the Webster formula on self-defense is it suggested that this fact might make a difference and that the Webster formula might not apply to armed attacks that did not emanate from a state.

The international reaction to the events of September 11, 2001 confirms the commonsense view that the concept of armed attack is not limited to State acts. The U.N. Security Council, in its resolutions 1368 and 1373 (2001), adopted in the immediate aftermath of the attacks, expressly recognized the right of self-defense in terms that could only mean it considered that terrorist attacks constituted armed attacks for the purposes of Article 51 of the Charter, ${ }^{43}$ since it was already likely, when these resolutions were adopted, that the attacks were the work of a terrorist organization rather than a state. Moreover, the Security Council's subsequent characterization of those acts as "armed attacks" was echoed by other international bodies. Thus, the North Atlantic Council, the governing body of NATO, stated on September 12, 2001:

If it is determined that this attack was directed from abroad against the United States, it shall be regarded as an action covered by Article 5 of the Washington Treaty, which states that an armed attack against one or more of the allies in Europe or North America shall be considered an attack against them all. ${ }^{44}$

41. Military and Paramilitary (Nicar. v. U.S.), supra note 6, at 102-03.

42. See text accompanying supra notes 15-18.

43. S.C. Res. 1368, U.N. SCOR, 56th Sess., 4370th mtg., pmbl. \& para. 3, U.N. Doc. S/RES/1368 (2001); S.C. Res. 1373, U.N. SCOR 56th Sess., 4385th mtg., pmbl. \& para. 4, U.N. Doc. S/RES/1373 (2001) [hereinafter S.C. Res. 1373].

44. Press Release, North Atlantic Council (Sept. 12, 2001), available at http://usinfo.state.gov/topical/pol/terror/01091205.htm (last visited Feb. 11, 2003). 
The Foreign Ministers of the Organization of American States, meeting in consultation, likewise invoked the 1947 Inter-American Treaty of Reciprocal Assistance in declaring that "these terrorist attacks against the United States of America are attacks against all American States".

\section{B. Collective Security}

The power of the Security Council to take military action is based on Chapter VII of the U.N. Charter. For the Council to exercise its powers under this Chapter it must first make a determination under Article 39, which provides:

The Security Council shall determine the existence of any threat to the peace, breach of the peace, or act of aggression and shall make recommendations, or decide what measures shall be taken in accordance with Articles 41 and 42, to maintain or restore international peace and security. 45

Once the Council has made such a determination, it can take decisions binding on all Member States of the United Nations. ${ }^{46}$ Those decisions may require States to take non-military measures, such as the imposition of sanctions. ${ }^{47}$ They may also require States to take actions such as withdrawal from territory occupied in a conflict, ${ }^{48}$ surrender of suspects for trial, ${ }^{49}$ or disarmament. ${ }^{50}$

The Council may not require States to take military action but it can authorize them to do so. ${ }^{51}$ That power stems from Article 42 of the Charter, which provides:

Should the Security Council consider that measures provided for in Article 41 would be inadequate or have proved to be inadequate, it may take such action by air, sea, or land forces as may be necessary to maintain or restore international peace and security. Such action may include demonstrations, blockade, and other operations by air, sea, or land forces of Members of the United Nations.

45. Although Article 39 does not say so, it is clear from the context that references to "peace and security" mean "international peace and security; see, e.g., the use of that term in U.N. CHARTER art. 42.

46. U.N. CHARTER art. 25.

47. U.N. CHARTER art. 41 .

48. See, e.g., S.C. Res. 660, U.N. SCOR, 45th Sess., 2392th mtg., U.N. Doc. S/RES/660 (1990) (requiring Iraq to withdraw from Kuwait).

49. See, e.g., S.C. Res. 827, U.N. SCOR, 48th Sess., 3217th mtg., U.N. Doc. S/RES/827 (1993) (on the International Criminal Tribunal for the Former Yugoslavia); S.C. Res. 1214 U.N. SCOR 53rd Sess., 3952nd mtg., U.N. Doc. S/RES/1214·(1998) (requiring the Taliban regime in Afghanistan to surrender for trial those responsible for the attack on the U.S. embassies in East Africa in 1998).

50. See, e.g., S.C. Res. 687, U.N. SCOR, 47th Sess., 2981 st mtg., U.N. Doc. S/RES/687 (1991) (on Iraq, discussed infra in Part IV.) [hereinafter S.C. Res. 687].

51. U.N. Charter art. 43, para. 1 (stating that States shall conclude agreements with the United Nations regarding which parts of their armed forces they will make available to the Security Council for collective security operations has never been implemented). In the absence of such agreements, the decision whether or not to make forces available for a collective security operation is entirely in the discretion of each State. 
Although this provision speaks of the Security Council "taking" military action, it has been used since the 1990-91 Gulf Conflict to authorize military action by groups of States to restore international peace and security.

\section{Collective Security and Pre-emptive Action}

There is no doubt that this power can be used pre-emptively. Indeed, the reference in Article 39 to "threat to the peace" (as distinct from "breach of the peace" and "act of aggression") as one of the three grounds on which the Council could exercise its Chapter VII powers, demonstrates that pre-emptive action was always intended to be a major feature of the regime of collective security created by the Charter. ${ }^{52}$

Nor does the Charter limit the pre-emptive power of the Security Council to threats that are "imminent". There is no trace of such a limitation anywhere in the Charter. On the contrary, the historical background against which the Charter was drafted-in particular, the importance of the lack of pre-emptive action against Hitler in the 1930's in contributing to the causes of World War Two--strongly suggests that the pre-emptive power of the Security Council was intended to be much more far-reaching than the power of individual States to take action by way of self-defense against threats of armed attack.

\section{Collective Security and Terrorism}

That leaves the question whether the concept of threat to the peace is broad enough to embrace not only threats emanating from States but also those created by a terrorist group like Al-Qaida. Although those who drafted the Charter were undoubtedly (and, given the historical background, understandably) concerned with threats posed by States, nothing in the language of Article 39 or the rest of the Charter suggests that only threats emanating from States can fall within its scope. In recent years, the Security Council has had no hesitation in treating acts of international terrorism, whether or not "State-sponsored", as threats to the peace for the purposes of Chapter VII of the Charter. Thus, even before September 11,2001, the Council had characterized as a threat to international peace and security Libyan support for terrorism, ${ }^{53}$ the

52. Jochen A. Frowein, Article 39, in THE Charter of THE United Nations: A COMMENTARy 720-21, paras. 6, 9 (Bruno Simma ed., 2nd ed. 2002).

53. S.C. Res. 748, U.N. SCOR, 47th Sess., 3063rd mtg., U.N. Doc. S/RES/748 (1992); S.C. Res. 883, U.N. SCOR, 48th Sess., 3312th mtg., U.N. Doc. S/RES/883 (1993); S.C. Res. 1192, U.N. SCOR, 53rd Sess., 2930th mtg., U.N. Doc. S/RES/11 192 (1998). 
attempted assassination of President Mubarak of Egypt ${ }^{54}$ and the attacks on the U.S. embassies in East Africa. ${ }^{55}$ Although the first case involved State action, there was no clear indication of State involvement in either of the other incidents. In addition, the Council adopted a number of resolutions condemning international terrorism in general as a threat to international peace. $^{56}$

The resolutions adopted by the Council in the aftermath of September 11, 2001 have been unequivocal in their condemnation of international terrorism and their characterization of it as a threat to international peace and security, which entitles the Council to exercise its Chapter VII powers. Resolution 1268 (2001), adopted unanimously on September 12 , 2001, expressed the determination of the Council "to combat by all means threats to international peace and security caused by terrorist acts" and condemned "the horrifying terrorist acts which took place on I1 September 2001" as being, "like any act of international terrorism ... a threat to international peace and security". In resolution 1373 (2001), which was also adopted unanimously, the Council repeated that characterization and, acting under Article 41 of the Charter, went on to require States to take extensive measures against the perpetrators and States suspected of assisting them. In addition, meetings of the Security Council held at ministerial level in November 2001 and January 2003 adopted declarations on terrorism, which were again based on the characterization of international terrorism as a threat to international peace and security. ${ }^{57}$

It seems clear, therefore, that under the collective security regime in the U.N. Charter, a State or group of States can be empowered to take military action to pre-empt threats of military action or terrorist activity and that the right to take such pre-emptive action is more extensive than is the case when a State acts in self-defense. It must be remembered, however, that the power to take action under the collective security regime can be conferred only by a decision of the Security Council. No state is entrusted under the Charter with the power to take military action to preserve or restore international peace and security without such a decision. In the absence of such a decision, only the more limited power to act in self-defense-individual or collective-remains.

54. S.C. Res. 1044, U.N. SCOR, 51 st Sess., 3627th mtg., U.N. Doc. S/RES/1044 (1996).

55. S.C. Res. 1189, U.N. SCOR, 53rd Sess., 3915th mtg., U.N. Doc. S/RES/1189 (1998); S.C. Res. 1267, U.N. SCOR,54th Sess., 4051 st mtg., U.N. Doc. S/RES/l267 (1999) [hereinafter S.C. Res. 1267].

56. See, e.g., S.C. Res. 1269, U.N. SCOR, 54th Sess., 4053rd mtg., U.N. Doc. S/RES/1269 (1999).

57. S.C. Res. 1377, U.N. SCOR, 56th Sess., 4413th mtg., U.N. Doc. S/RES/1377 (2001); S.C. Res. 1456, U.N. SCOR, 58th Sess., 4688th mtg., U.N. Doc. S/RES/1456 (2003). 


\section{THE USE OF ForCE AgAINST INTERNATIONAL TERRORISM}

An analysis of the military action which followed September 11, 2001 in the light of the legal framework set out in Part II., the first point to note is that the United States and its allies consistently based their justification for military action in Afghanistan, and against Al-Qaida more generally, on the right of self-defense and not on any collective security mandate from the Security Council.

The reliance on self-defense is evident in the letters sent by, for example, the governments of the United States and the United Kingdom to the Security Council reporting on the measures that they were taking in Afghanistan. $^{58}$ On October 7, 2001, the U.S. Ambassador to the United Nations, John Negroponte, wrote to the President of the Security Council "to report that the United States of America, together with other States, has initiated actions in the exercise of its inherent right of individual and collective self-defense following the armed attacks that were carried out against the United States on September 11, 2001". 59 The letter went on to state that the United States had "clear and compelling information that the AlQaida organization ... had a central role in the attacks" and further stated that the United States might find "that our self-defense requires further actions with respect to other organizations and states". The letter continued:

The attacks on September 11, 2001 and the ongoing threat to the United States and its nationals posed by the Al-Qaida organization have been made possible by the decision of the Taliban regime to allow the parts of Afghanistan that it controls to be used by this organization as a base of operation. Despite every effort by the United States and the international community, the Taliban regime has refused to change its policy. From the territory of Afghanistan, the AlQaida organization continues to train and support agents of terror who attack innocent people throughout the world and target United States nationals and interests in the United States and abroad.

In response to these attacks, and in accordance with the inherent right of individual and collective self-defense, United States armed forces have initiated actions designed to prevent and deter further attacks on the United States. These actions include measures against Al-Qaida terrorist training camps and military installations of the Taliban regime in Afghanistan. In carrying out these actions, the United States is committed to minimizing civilian casualties and damage to civilian property.

58. U.N. ChaRTER art. 51. The second sentence of Article 51 of the Charter requires states taking action in self-defense to make such reports.

59. U.N. SECURITY COUNCIL, LETTER DATED 7 OCTOBER 2001 FROM THE Permanent Representative of the United States of America to the United Nations AdDressed to THE President of the SECurity Council, U.N. Doc. S/2001/946 (2001). 
The U.K. chargé d'affaires wrote to the Security Council in similar terms on the same day. His letter stated that U.K. forces were engaged in military operations in Afghanistan and continued:

\begin{abstract}
These forces have now been employed and exercised the inherent right of individual and collective self-defence, recognised in Article 51, following the terrorist outrage of 11 September, to avert the continuing threat of attacks from the same source. My Government presented information to the United Kingdom Parliament on 4 October which showed that Usama bin Laden and his Al-Qaida terrorist organisation have the capability to execute major terrorist attacks, claimed credit for past attacks on United States targets, and have been engaged in a concerted campaign against the United States and its allies. One of the stated aims is the murder of United States citizens and attacks on the allies of the United States.

This military action has been carefully planned and is directed against Usama bin Laden's Al-Qaida terrorist organisation and the Taliban regime that is supporting

it. Targets have been selected with extreme care to minimise the risk to civilians. ${ }^{60}$
\end{abstract}

Did the right of self-defense in fact provide a satisfactory legal basis for military action in Afghanistan? In answering this question, four issues require examination. First, should the United States and its allies have obtained Security Council authorization before resorting to force? The answer is that there is clearly no legal requirement for them to do so. The right of self-defense preserved by Article 51 of the Charter is vested in states and its exercise requires no prior permission from the Security Council. The only sense in which the exercise of the right of self-defense is dependent upon the Security Council is found in the provision, in the first sentence of Article 51, that when the Security Council has "taken measures necessary to maintain international peace and security", the right of self-defense lapses. That clause in Article 51 has, however, generally been the subject of restrictive interpretation. ${ }^{61}$ Moreover, although resolution 1373 (2001) adopted a wide range of non-military measures for the purpose of restoring international peace and security, the Council expressly reaffirmed the right to self-defense and thus made clear that it did not regard the resolution as in any way restricting the United States in the exercise of that right. ${ }^{62}$

Secondly, was the action by the United States and its allies a response to an armed attack within the meaning of Article 51? It has already been suggested that the concept of armed attack is not limited to State action and that the attacks of September 11, 2001 undeniably met the requirement of gravity identified by the International Court of Justice in

60. U.N. SECuRITy Council, LeTter Dated 7 OCtober 2001 from THE Charge D'Affaires a.l. of the Permanent Mission of the United Kingdom of Great BRITAIN AND NORTHERN IRELAND to THE UNITED NATIONS ADDRESSED TO THE PRESIDENT OF THE SECURITY COUNCIL, U.N. Doc. S/2001/947 (2001).

61. See generally Christopher Greenwood, New World Order or Old?: The invasion of Kuwait and the Rule of Law, 55 MODERN L. REv. 153, 164-65 (1992).

62. See S.C. Res. 1373, supra note 43 , at para. 4. 
the Nicaragua case. Nevertheless, the attacks of September 11, 2001, terrible as they were, took place some weeks before the U.S. military response was commenced. Self-defense, which is lawful in international law, has to be carefully distinguished from reprisals, which, if they involve the use of armed force, are no longer lawful under the U.N. Charter. The requirement of necessity in self-defense means that it not sufficient that force is used after an armed attack, it must be necessary to repel that attack. The use of force in response to an armed attack that is over and done with does not meet that requirement and looks more like a reprisal. The U.S. action has therefore been criticized for constituting what some consider to have been a reprisal, rather than a genuine action in self-defense.

That criticism is unconvincing. The events of September 11 cannot be considered in isolation. Taken together with other events, such as the attacks on the U.S. embassies in East Africa in 1998 and the attack on the USS Cole for which Al-Qaida had claimed responsibility, there were the clearest possible indications of further outrages to come. Moreover, in these circumstances there seems little difficulty in regarding the threat of future attacks from Al-Qaida as meeting the criteria of imminence. That was clearly the view of the governments of the United States and the United Kingdom, whose letters to the Security Council both spoke of averting future attacks from Al-Qaida. Whatever criticism this may have evoked from commentators, ${ }^{63}$ it appears to have met with no hostility from states, even from those normally opposed to U.S. positions. Therefore, as long as the military action in Afghanistan is viewed as a forward looking measure to prevent an imminent threat from materializing into violence, rather than as a backward looking act of retaliation for the events of September 11, 2001, this criterion of selfdefense appears to be satisfied.

Thirdly, did the threat of armed attack from Al-Qaida justify military action against Afghanistan? This is a more difficult question for several reasons. Had the relationship between Al-Qaida and the state of Afghanistan been such that Afghanistan could be held responsible in international law for the attacks of September 11, and other threats from Al-Qaida, there would have been no difficulty. The United States would then have been employing force against the state responsible for past

63. See Michael Byers, Terrorism, the Use of Force and International Law After II September, 51 INT'L \& COMP. L.Q. 401 (2002). 
armed attacks and the threat of future armed attacks upon it. However, the criteria for determining the responsibility of a state for the acts of a private organization are not altogether clear. In the Nicaragua case, the International Court held that the relationship between the United States and the Contra rebel movement in Nicaragua was not close enough to render the United States responsible for illegal acts committed by the Contras. The Court held:

For this conduct to give rise to legal responsibility of the United States, it would in principle have to be proved that that state had effective control of the military or paramilitary operations in the course of which the alleged violations were committed. ${ }^{64}$

That test has largely been adopted by the International Law Commission in its Articles on State Responsibility ${ }^{65}$ although the International Criminal Tribunal for the Former Yugoslavia in its second decision in Tadic $^{66}$ suggests a looser standard. However, the evidence of the relationship between Al-Qaida and Afghanistan makes it difficult to conclude that either test had been satisfied.

A further complication is that the Taliban regime in Afghanistan was not recognized as the government of Afghanistan by the United States or the vast majority of other countries. That, however, makes no substantial difference. There is no doubt that the Taliban regime was the de facto government in Afghanistan at the relevant time and that the state of Afghanistan bore responsibility for its actions. ${ }^{67}$ The most important point, however, is that the state of Afghanistan, through the acts of the Taliban regime, had undoubtedly violated international law in permitting Al-Qaida to operate from its territory. There is a general duty under international law for a state not to allow its territory to be used as a base for attacks on other states, whether by regular armed forces or terrorists. ${ }^{68}$ In addition, Afghanistan violated specific obligations imposed by the Security Council following the embassy attacks in $1998 .^{69}$ At the very least, its position was analogous to that of a neutral

64. Military and Paramilitary Activities (Nicar. v U.S.), supra note 6, at 65 .

65. INTERNATIONAL LAW COMMISSION, ARTICLES ON STATE RESPONSIBILITY, art. 8. See James Crawford, The InTERnational LaW COMmission's articles on STATE RESPONSIBILITY: INTRODUCTION, TEXT, AND COMMENTARIES 110-13 (2002).

66. International Criminal Tribunal for the Former Yugoslavia-Appeals Chamber: Prosecutor v. Tadic, 38 I.L.M. 1518, 1541 (1999).

67. Ruidiger Wolfrum \& Christiane E. Philipp, The Status of the Taliban: Their Obligations and Rights Under International Law, 6 MAX PLANCK Y.B. OF UN L. 559 (2002).

68. United Nations General Assembly definition of aggression, resolution 3314 (XXIX), and numerous other resolutions of the Security Council and the General Assembly bear witness to such a duty.

69. See S.C. Res. 1267, supra note 55; S.C. Res. 1333, U.N. SCOR, 55th Sess., 4251 st mtg., U.N. Doc. S/RES/1333 (2000). 
state that unlawfully allows a belligerent to mount military operations from its territory. Even though the neutral is not held responsible for those operations as such, it exposes itself to the risk of lawful military action to put a stop to them. Similarly, where a state allows terrorist organizations to mount concerted operations against other states from its territory, and refuses to take the actions required by international law to put a stop to such operations, the victims of those operations are entitled to take action against those terrorists. The Caroline formula on selfdefense clearly permitted such action and the undoubted changes in international law since that time have not abolished this aspect of the right of self-defense. Because the Taliban regime made it clear throughout that it would vigorously oppose any foreign forces entering its territory to root out Al-Qaida bases, it exposed its own forces to lawful attack in exercise of the right of self-defense.

Finally, the action taken in self-defense needed to be necessary and proportionate. Faced with the prospect of more attacks as devastating as those of September 11, it is difficult to see how the United States went beyond what was necessary. It was also proportionate. Although the effect of United States and allied intervention in Afghanistan was to change the balance of the civil war taking place in that country and lead to the overthrow of the Taliban regime and its replacement by a new government, it is difficult to see how the intervention could have succeeded in its aims of removing the Al-Qaida bases in Afghanistan without going that far. Indeed, there would rightly have been much criticism of the United States and its allies had their intervention been accomplished while leaving the people of Afghanistan in the same plight as they were in beforehand.

The pre-emptive action that the United States and its allies took against Al-Qaida in Afghanistan was, therefore, a lawful exercise of the right of self-defense. It would, however, be a mistake to assume that self-defense would cover every military action that the United States or an ally might want to take against Al-Qaida (or other terrorist groups) in other countries. The use of force in Afghanistan fell within the concept of self-defense because the threat from Al-Qaida was imminent and because Afghanistan was quite openly affording sanctuary to large numbers of Al-Qaida personnel. These considerations will not necessarily be present in every case. 


$$
\text { IV. IRAQ }{ }^{70}
$$

The military action against Iraq, which commenced in March 2003 also raises questions about the scope for pre-emptive military action in international law. Before those questions can be addressed, however, it is necessary to examine the background to the present situation because the legal position in 2003 can be understood only in the context of the actions taken by the U.N. Security Council over the years since the Iraqi invasion of Kuwait in August 1990.71

\section{A. The Security Council Resolutions on Iraq}

That invasion, which was a flagrant violation of international law, was condemned by the Security Council in resolution 660 (1990), which required Iraq to withdraw from Kuwait. In common with most of the subsequent resolutions on Iraq, this resolution was adopted under Chapter VII of the U.N. Charter and its provisions were therefore legally binding on Iraq. When Iraq ignored the requirement that it withdraw, the Security Council adopted a series of further resolutions. For present purposes, the most important is resolution 678 (1990) by which the Council authorized:

\footnotetext{
Member States co-operating with the Government of Kuwait, unless Iraq on or before January 15, 1991 fully implements, as set forth in paragraph 1 above, the [earlier Security Council resolutions on Kuwait] to use all necessary means to uphold and implement resolution 660 (1990) and all subsequent relevant resolutions and to restore international peace and security in the area. (Emphasis added.)
}

The reference to "all necessary means" was clearly understood to be an authorization of military action. ${ }^{72}$ The passage emphasized shows that that authorization was not limited to the liberation of Kuwait but included an authority to use all necessary means for the purpose of restoring peace and security in the area.

The fighting that ensued was brought to an end at the beginning of March 1991 with the adoption of resolution 686 (1991). In April 1991, the Council went on to lay down an exhaustive list of requirements Iraq had to meet as the conditions for a permanent ceasefire. It did so in resolution 687 (1991), which referred to all of the earlier resolutions on Iraq, including resolution 678 . In paragraph 1 of resolution 687 , the

70. For discussion of this topic see Report of the United Kingdom House of Commons Foreign Affairs Committee, Foreign Policy Aspects of the War against Terrorism, H.C. (2002-03) No. 196, para. 129-61; Memoranda by Professors Brownlie and Greenwood reprinted with the Appendices to the report; Judgment of Professor Vaughan Lowe for the $\mathrm{BBC}$ hearing on the legality of use of force against Iraq, at http://www.bbc.co.uk/cgi-bin/education/betsie/parser.pl.

71. For a discussion of the 1990-91 conflict with Iraq see Greenwood, supra note 61 .

72. Id. at $165-67$. 
Council "affirms all thirteen resolutions noted above, except as expressly changed below to achieve the goals of the present resolution, including a formal cease-fire." (Emphasis added.) One of those goals (as noted in preambular paragraph 25) was the restoration of peace and security in the area, something that had not been brought about simply because Kuwait had been liberated. Resolution 687 laid out what the Council determined Iraq had to do to achieve that goal. The Council required that Iraq:

[U]nconditionally accept the destruction, removal, or rendering harmless, under international supervision, of:

(a) all chemical and biological weapons and all stocks of agents and all related subsystems and components and all research, development, support and manufacturing facilities related thereto;

(b) all ballistic missiles with a range greater than one hundred and fifty kilometres, and related major parts and repair and production facilities. ${ }^{73}$

In addition, paragraph 12 of resolution 687 required Iraq "not to acquire or develop nuclear weapons or nuclear weapon usable material or any subsystems or components or any research, development, support or manufacturing facilities related to the above." The onus was on Iraq to demonstrate that it had complied with these requirements and to that end the Council established a weapons inspectorate (UNSCOM) and empowered the IAEA to fulfill the same role as UNSCOM with regard to Iraq's nuclear program. ${ }^{74}$ Other provisions of resolution 687 required Iraq not to commit or support any act of terrorism and not to permit any terrorist organization to operate from its territory. ${ }^{75}$ All of these requirements went directly to what the Council regarded as necessary to ensure a restoration of peace and security in the area.

Iraq formally accepted these requirements but resolution 687 was legally binding because of the obligations imposed on Iraq by Article 25 and Chapter VII of the U.N. Charter, not because of Iraq's acceptance of the resolution. The resolution was not the equivalent of an agreement.

In fact, Iraq never complied with the ceasefire conditions and was repeatedly found by the Security Council to be in breach of the requirements of resolution 687 regarding international peace and security. For example, resolutions 707 (1991), 949 (1994), 1060 (1996),

73. S.C. Res. 687 , supra note 50 , at para. 8.

74. The IAEA was charged with responsibility for investigating Iraq's nuclear weapons program. Responsibility for investigating all other relevant weapons programs was entrusted to UNSCOM, a body later replaced by UNMOVIC in 1999; see discussion infra Part IV.A.

75. S.C. Res. 687 , supra note 50 , at para. 32. 
1115 (1997), and 1137 (1997) all condemned Iraqi violations of provisions of resolution 687. In 1998 the U.N. Secretary-General drew up a Memorandum of Understanding with Iraq regarding weapons inspections. The Security Council then, in resolution 1154 (1998) stressed:

[C]ompliance by the Government of Iraq with its obligations, repeated again in the Memorandum of Understanding, to accord immediate, unconditional and unrestricted access to the Special Commission and the IAEA in conformity with the relevant resolutions is necessary for the implementation of resolution 687 (1991), but that any violation would have severest consequences for Iraq.

Nevertheless, Iraq continued to violate its obligations, a fact demonstrated, for example, by resolution 1205 (1998). After yet another attempt to resume inspections, UNSCOM reported to the Security Council on December 15, 1998:

\begin{abstract}
As is evident from this report, Iraq did not provide the full cooperation it promised on November 14, 1998.

In addition, during the period under review, Iraq initiated new forms of restrictions upon the Commission's work. Amongst the Commission's many concerns about this retrograde step is what such further restrictions might mean for the effectiveness of long-term monitoring activities.

In spite of the opportunity presented by the circumstances of the last month, including the prospect of a comprehensive review, Iraq's conduct ensured that no progress was able to be made in either the fields of disarmament or accounting for its prohibited weapons programs.

Finally, in the light of this experience, that is, the absence of full cooperation by Iraq, it must regrettably be recorded against [sic] that the commission is not able to conduct the substantive disarmament work mandated to it by the Security Council and, thus, to give the assurances it requires with respect to Iraq's prohibited weapons programs. ${ }^{76}$
\end{abstract}

This report was followed by the withdrawal of the UNSCOM inspectors and a period of military action (Operation Desert Fox) by the United Kingdom and United States against targets in Iraq connected with unlawful Iraqi weaponry. ${ }^{77}$ Resolution 1284 (1999) replaced UNSCOM with a new body, UNMOVIC, and required that Iraq allow UNMOVIC unrestricted access. Iraq, however, refused to permit UNMOVIC to operate within Iraq until it suddenly changed tack in September 2002 and agreed that the inspectors could return.

76. U.N. SECURITY COUNCIL, LETTER DATED 15 DECEMBER 1998 FROM THE Secretary General, Addressed to the President of the Security Council, U.N. Doc. S/1998/1172 (1998).

77. See United Kingdom Statement at U.N. SCOR, 53rd Sess., 3939th mtg., at 10, U.N. Doc. S/PV.3939 (1998), at http://ods-dds-ny.un.org/doc/UNDOC/PRO/N98/863/ 20/PDF/N9886320.pdf?OpenElement. Operation Desert Fox should not be confused with the quite separate Anglo-American actions to maintain "no-fly zones" established in northern and southern Iraq. The legal basis for the "no-fly zones" is humanitarian action in support of Security Council resolution 688 (1991). See Christopher Greenwood, Is there a Right of Humanitarian Intervention?, 39 WORLD TODAY 34 (Feb. 1993). 
It was against this background that the Security Council unanimously adopted resolution 1441 (2002) on November 8, 2002. That resolution again expressly recalled resolution 678 (1990) and deplored the fact that Iraq had not complied with resolution 687 (1991). The Council recalled that resolution 687 had stated that "a ceasefire would be based on acceptance by Iraq of the provisions of that resolution, including the obligations on Iraq contained therein."78 The resolution then stated that the Council:

\section{Decides that Iraq has been and remains in material breach of its obligations under relevant resolutions, including resolution 687 (1991), in particular through Iraq's failure to cooperate with United Nations inspectors and the IAEA, and to complete the actions required under paragraphs 8 to 13 of resolution $687(1991){ }^{79}$}

The term "material breach" has a special meaning in the law of treaties. In Article 60(3) of the Vienna Convention on the Law of Treaties, 1969, material breach is defined as:

(a) a repudiation of the treaty not sanctioned by the present Convention; or,

(b) the violation of a provision essential to the accomplishment of the object or purpose of the treaty.

At the Security Council meeting that adopted resolution 1441, Ireland stated that it understood the term "material breach" in the resolution to have the meaning set out in this Article. ${ }^{80}$ Of course, resolution 687 is not a treaty but a unilateral act of the Security Council, more akin to a legislative instrument, which binds Iraq irrespective of its agreement. However, it is unlikely that anything will turn on this point. The object and purpose of resolutions 687 and 1441 is plainly to restore international peace and security and a material breach of its terms is therefore one that involves a violation of a provision essential to the accomplishment of that object. That includes the possession by Iraq of prohibited weapons, or the failure to cooperate actively with the inspectors, because the inspection mechanism is itself essential to the accomplishment of the purpose of the resolution. As a leading text on the law of treaties has stated, "material breach" is not the same as "fundamental breach" but can include the breach of an important ancillary provision such as one providing for monitoring and verification. ${ }^{81}$

78. S.C. Res. 1441, U.N. SCOR 57th Sess., 4644th mtg., pmbl., U.N. Doc. S/RES/1441 (2002) [hereinafter S.C. Res. 1441].

79. Id. at para. 1 .

80. U.N. SCOR 57th Sess., 4644th mtg., at 7-8, U.N. Doc. S/PV.4644 (2002), at http://ods-dds-ny.un.org/doc/UNDOC/PRO/N02/680/99/PDF/N0268099.pdf?OpenElement.

81. ANTHONY AUST, MOdern TREATY LAW AND PRACTICE 238 (2000) (referring to the inspection provisions of the Chemical Weapons Convention). 
The Council, however, decided "to afford Iraq ... a final opportunity to comply with its disarmament obligations" under resolution 687 and the other resolutions. ${ }^{82}$ Iraq was required to submit "a currently accurate, full and complete declaration of all aspects of its programs to develop chemical, biological and nuclear weapons, ballistic missiles, and other delivery systems" as well as allow unrestricted access to inspectors from UNMOVIC and the IAEA. ${ }^{83}$ The Council decided:

[T] hat false statements or omissions in the declarations submitted by Iraq pursuant to this resolution and failure by Iraq at any time to comply with, and cooperate fully in the implementation of, this resolution shall constitute a further material breach of Iraq's obligations and will be reported to the Council for assessment in accordance with paragraphs 11 and 12 below; ${ }^{84}$

... further that Iraq shall not take or threaten hostile acts directed against any representative or personnel of the United Nations or the IAEA or of any Member State taking action to uphold any Council resolution. ${ }^{85}$

Paragraph 9 required Iraq to cooperate "immediately, unconditionally and actively". In the event of Iraqi non-compliance, paragraphs 11 to 13 of the resolution provided that the Council:

11. Directs the Executive Chairman of UNMOVIC and the Director-General of the IAEA to report immediately to the Council any interference by Iraq with inspection activities, as well as any failure by Iraq to comply with its disarmament obligations, including its obligations regarding inspections under this resolution;

12. Decides to convene immediately upon receipt of a report in accordance with paragraphs 4 or 11 above, in order to consider the situation and the need for full compliance with all of the relevant Council resolutions in order to secure international peace and security;

13. Recalls, in that context, that the Council has repeatedly warned Iraq that it will face serious consequences as a result of its continued violations of its obligations.

Resolution 1441 was based on a draft resolution sponsored by the United Kingdom and the United States. The draft was the subject of extensive informal consultations over a period of weeks before any text was made public. It is, therefore, impossible to be certain what changes may have been made in these informal negotiations or what understandings expressed about the meaning of different provisions in the resolution. A draft resolution, which reflected these informal consultations, was published on November $6,2002 .{ }^{86}$ The text finally adopted differed from that draft in that the reference in paragraph 12 of the draft to the Council meeting "in order to consider the situation and the

82. Id. at para. 2 .

83. Id. at para. 3 .

84. Id. at para. 4 .

85. Id. at para. 8 .

86. U.N. SECURITY COUNCIL, UNITED KINGDOM OF GREAT BRITAIN AND NORTHERN IRELAND AND UNITED STATES OF AMERICA: DRAFT RESOLUTION, U.N. Doc. S/2002/1 198 (2002). 
need for full compliance with all of the relevant resolutions in order to restore international peace and security" was changed by substituting the word "secure" for "restore". It has been suggested that this change weakens the argument that the resolution could provide an authority for the use of force because the change meant that the language of the resolution no longer tracked so closely the language of resolution 678 (1990). ${ }^{87}$ The minor alteration in the language, however, seems a very slender basis for any such conclusion.

As required by resolution 1441, Iraq produced on December 7, 2002 a declaration relating to all its relevant weapons programs. It also admitted teams of inspectors from UNMOVIC and the IAEA. On January 27, 2003, the Executive Chairman of UNMOVIC, Dr. Hans Blix, and the DirectorGeneral of the IAEA, Mr. Mohammed El Baradei presented reports to the Security Council detailing the activities and findings of their teams during the first sixty days of inspections. ${ }^{88}$ Dr. Blix's report showed that Iraq was still not in compliance with resolution 1441 and the other relevant resolutions. Although noting that Iraq had generally cooperated in terms of access (though he noted some problems), Dr. Blix found Iraq's cooperation on matters of substance wanting. Iraq had not provided the kind of active cooperation that resolution 1441 required; in particular, Iraq had not volunteered evidence from which unresolved questions about weaponry raised in previous inspections might be resolved. Specifically, Dr. Blix expressed concern about:

(1) evidence that Iraq had made greater progress in purifying and weaponizing VX nerve gas than it had admitted; 89

(2) documents relating to the use of chemical bombs in the IranIraq war, which suggested that some 6500 chemical bombs, with approximately 1000 tonnes of chemicals, were unaccounted for; 90

(3) the discovery of a small number of chemical rocket warheads, which highlighted the issue of rockets, had not been accounted for; 91

87. Frederic Kirgis, Security Council Resolution 1441 on Iraq's Final Opportunity to Comply with Disarmament Obligations, ASIL INSIGHTS, Nov. 2002, available at http://www.asil.org/insights/insigh92.htm (last visited Feb. 3, 2003).

88. U.N. Doc. S/PV.4692, supra note 3.

89. Id. at 5

90. Id.

91. Id. 
(4) indications that Iraq had produced more anthrax than it had declared and that it might have retained some bacterial growth media possibly sufficient to produce 5000 liters of anthrax ${ }^{92}$

(5) evidence that Iraq had continued to develop missiles with a range of more than 150 kilometers; 93

(6) a discovery of documents in the home of an Iraqi scientist, which suggested that other documents might, have been placed in private homes so as to make their detection more difficult; 94

(7) the unwillingness of Iraqi scientists to meet inspectors other than in the presence of Iraqi officials. ${ }^{95}$

The Blix Report also noted that UNMOVIC had built up its capabilities, which were at the disposal of the Security Council. ${ }^{96}$ Dr. El Baradei also noted certain matters that his team was investigating but stated that "to date we have found no evidence that Iraq has revived its nuclear weapons programme since the elimination of the programme in the 1990s".

Dr. Blix and Dr. El Baradei briefed the Council again on February $14^{98}$ and March 7, 2003. ${ }^{99}$ In addition, UNMOVIC produced on March 6, 2003 a detailed document entitled "Unresolved Disarmament Issues". ${ }^{100}$ Although these reports referred to progress and a number of concessions on the part of the Iraqi government, they also established that, four months after the adoption of resolution 1441, Iraq had still not taken all the steps required to put an end to the continuing breach identified in paragraph 1 of resolution 1441. At the meeting of the Security Council on March 7, 2003, when Iraq's representative contended that Iraq had no weapons of mass destruction and was cooperating fully with the inspectors, ${ }^{101}$ not one member of the Council agreed that Iraq had yet put an end to the material breach of resolution 687, which the Council had earlier identified and most made express statements that Iraq was still in breach, although there were evident differences about the extent of that breach and about the best way in which to respond to it. ${ }^{102}$

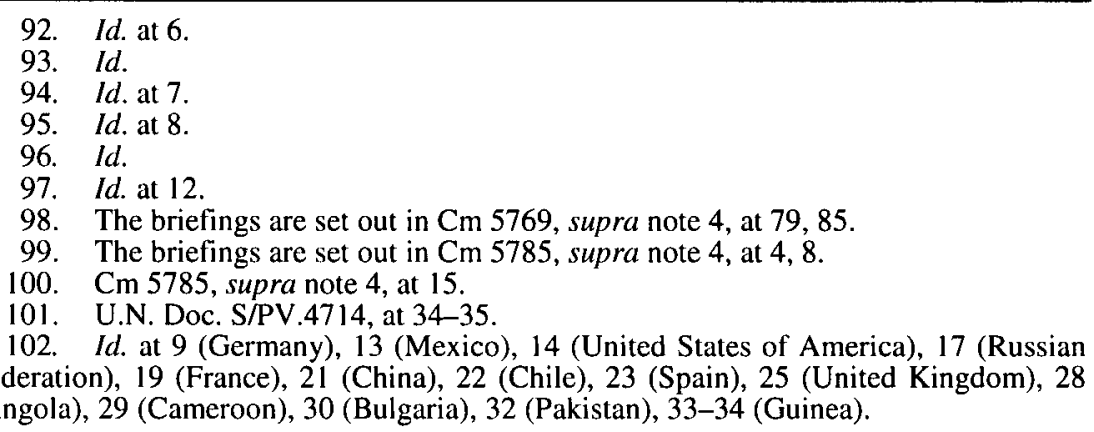


The differences over whether to resort to force or whether to continue with the inspections meant, however, that the Council was effectively deadlocked. By March 16 it had become clear that neither a resolution that would authorize military action (or one which would be perceived as doing so) or a resolution that the inspectors should continue with their work would be adopted. In these circumstances, the United States, the United Kingdom, and a number of other States decided to take military action without a further resolution, relying on the authorization granted by resolution $678(1990){ }^{103}$ That action began on March 20, 2003.

\section{B. The Legality of Military Action Against Iraq}

Was that resort to force lawful? This question certainly aroused controversy with several States expressing the view that it was not, while others strongly defended the action. ${ }^{104}$ In the light of the Blix Reports and the "Unresolved Issues" document published by UNSCOM, ${ }^{105}$ it is plain that, at the date military action commenced, Iraq continued to be in material breach of resolution 1441 (2002) and resolution 687 (1991). The debate in the Council on March 7, 2003 showed that, with the possible exception of Syria, all the members of the Council accepted that this was the case. ${ }^{106}$ Moreover, that breach was no technicality but meant that, on the basis of the existing Security Council resolutions, Iraq posed a threat to international peace and security as determined by the Security Council.

In those circumstances, there is no doubt that the Council could lawfully have adopted a fresh resolution authorizing military action. Resolution 1441 (2002) did not, in and of itself, constitute such a fresh mandate. The text of that resolution made clear that any breach by Iraq was to be reported to the Council, which would then "convene... in order to consider the situation and the need for full compliance with all of the relevant Council

103. The British government's exposition of this argument was set out in an answer by the Attorney-General, Lord Goldsmith, to a parliamentary question on March 17, 2003, 646 PARL. Deb. H.L. WA 2, and a longer paper on the legal basis for action sent by the Secretary of State for Foreign and Commonwealth Affairs to the Foreign Affairs Committee of the House of Commons, at http://www.fco.gov.uk/servlet/Front?pagename=OpenMarket/Xcelerate/ ShowPage \& $c=$ Page\&cid=1007029394383\&a=KArticle\&aid $=1047661460790$.

104. See also the differing views expressed in the United Kingdom Parliament, e.g., in the debate on the Legality of the Use of Force in the House of Lords on March 17, 2003, 646 PARL. DEB. H.L. WA cols. 68 et seq.

105. See discussion supra note 100.

106. See the statements cited supra note 102 . 
resolutions in order to secure international peace and security". ${ }^{107}$ Moreover, several States made clear when the resolution was adopted that there was no "automaticity" involved, ${ }^{108}$ so that any violation by Iraq would have to be discussed by the Council before any recourse to force.

A new resolution expressly authorizing military action was not, however, necessary as a matter of international law. The authorization to use "all necessary means" contained in resolution 678 (1990) had not been terminated by the Security Council. On the contrary, as demonstrated above, it was reaffirmed, as recently as November 2002, in the preamble to resolution 1441 (2002). Contrary to what is frequently suggested, ${ }^{109}$ resolution 678 was not solely about the liberation of Kuwait. The authorization for the coalition to use force went beyond the goal of liberating Kuwait by authorizing military action for the purpose of restoring international peace and security in the area.

Resolution 687 (1991) then determined that the restoration of international peace and security required the partial disarmament of Iraq. Resolution 687, paragraph 1, affirmed Resolution 678 except to the extent that the other provisions of resolution 687 expressly changed resolution 678. The text of resolution 687 contained nothing that expressly (or impliedly) indicated that the Council either considered that the mandate contained in resolution 678 had been discharged or that it could not be relied upon in the event of Iraq continuing to pose a threat to international peace and security. The imposition of a ceasefire by resolution 687 (1991) suspended hostilities and thus suspended the authority to use force but, by reaffirming resolution 678, resolution 687 left open the possibility of further military action to achieve the objectives of resolution 678 in the event of Iraqi violation of the ceasefire terms.

It is, of course, true that resolution 678 was not intended to remain in force indefinitely. ${ }^{110}$ But that fact is not decisive. The same could be said of resolution 661 (1990) imposing economic sanctions. The Council plainly intended that neither resolution should remain in force longer than was necessary to ensure Iraqi compliance with the various resolutions on Kuwait and to restore peace and security in the area. Following the liberation of Kuwait, resolution 687 (1991) set out exactly what the Council considered had to be done by Iraq to ensure that peace and security was restored but Iraq did not do what was required of it. That resolution 678 (1990) remained in force, therefore, was due solely to Iraq's persistent violation of its obligations under

107. S.C. Res. 1441, supra note 79 , at para. 12 :

108. See, e.g., Statement by the United States, S/PV.4644, at 3; Statement by the United Kingdom, id. at 5. See also U.N. SeCURITY COUNCIL, LETTER DATED 8 NOVEMBER 2002 FROM THE REPRESENTATIVES OF CHINA, FRANCE AND THE RUSSIAN FEDERATION TO THE UNITED NATIONS ADDRESSED TO THE PRESIDENT OF THE UNITED NATIONS, U.N. Doc. S/2002/1236 (2002).

109. See, e.g., answer by Professor Brownlie in response to Question 89, supra note 70.

110. Lowe, supra note 70 , at para. 115. 
resolution 687. Moreover, the recent reaffirmation of resolution 678 (1990) in the preamble to resolution 1441 (2002) cannot be dismissed as mere verbiage; the only possible interpretation of that paragraph in the preamble was that the Council (unanimously) considered that the earlier resolution was still in force.

The principle that the authorization of force contained in resolution 678 could revive in the event of Iraqi violation of the ceasefire conditions in resolution 687 was relied on by the United Kingdom and the United States in January 1993. ${ }^{11}$ That action - and the legal justification advanced for itreceived support from the Secretary-General of the United Nations, who said:

The raid yesterday, and the forces that carried out the raid, have received a mandate from the Security Council according to resolution 678 and the cause of the raid was the violation by Iraq of resolution 687 concerning the ceasefire.

So, as the Secretary-General of the UN, I can say that this action was taken and conforms to the resolutions of the Security Council and conforms to the Charter of the United Nations. ${ }^{112}$

This principle was also invoked by the United Kingdom and the United States in December 1998 at the time of Operation Desert Fox. ${ }^{113}$

The decision by the Council, in paragraph 1 of resolution 1441 (2002), that Iraq was guilty of a continuing material breach of the conditions of resolution 687 (1991) showed that the conditions for the revival of the authority to use force existed. The use of the term "material breach" in resolution 1441 was particularly significant as it was the term that had been used by the Council at the time of the 1993 recourse to force. The decision to grant Iraq a final opportunity to comply, however, together with the requirement that any failure on the part of Iraq to take that opportunity had to be reported to the Council for consideration under paragraph 12 of resolution 1441, meant that resolution 1441 did not automatically revive the authorization of military action. ${ }^{114}$ Nevertheless, the requirement in paragraph 12 of resolution 1441 that the Council consider the matter, did not mean that no action could be taken under resolution 678 unless the Council decided on such a course. As the British government's statement on the legal basis for military action made clear:

111. See, e.g., the statements by the U.K. government reproduced in 64 BRIT. Y.B. INT'L L. 736 (1993).

112. IRaQ and Kuwait: The Hostilities and Their AfTermath 741-42 (Marc Weller ed., Cambridge 1993).

113. See supra text accompanying notes 77-78. For criticism of this reliance on resolution 678 see Christine Gray, From Unity to Polarisation: International Law and the Use of Force Against Iraq, 13 EUR. J. INT'L L. 1 (2002).

114. Hence the statements about there being no automaticity. See discussion supra note 108 and accompanying text. See also Foreign Secretary's statement, supra note 103, at para. 11. 
Had that been the intention, [resolution 1441] would have provided that the Council would decide what needed to be done to restore international peace and security, not that it would consider the matter. The choice of words was deliberate; a proposal that there should be a requirement for a decision by the Council, a position maintained by several members, was not adopted. Instead the members of the Council opted for the formula that the Council must consider the matter before any action is taken. ${ }^{115}$

In accordance with paragraph 12 of resolution 1441, the Council did consider the matter at several formal meetings and in numerous informal consultations between its members. Those meetings and consultations showed that the members of the Council were agreed that Iraq remained in material breach of its disarmament obligations but disclosed that the members were divided about what to do with the result that no decision could be taken. In these circumstances, although it must be recognized that others have taken a different view, the present writer believes that those governments who resorted to force were right to conclude that they could rely on the authorization of military action in resolution 678 , read together with resolutions 687 and 1441 .

\section{CONCLUSIONS}

In his State of the Union address on January 28, 2003, President George W. Bush highlighted the importance of pre-empting attacks such as the one that occurred on September 11, 2001. In doing so, he made the following remark:

Some have said that we must not act until the threat is imminent. Since when have terrorists and tyrants announced their intentions, politely putting us on notice before they strike. If this threat is permitted to fully and suddenly emerge, all actions, all words and all recriminations would come too late. ${ }^{116}$

This Article has sought to demonstrate that international law does not require that States wait until it is too late but nor does it give a broad general license for pre-emptive military action. The following conclusions seem warranted:

(1) All States have the right of self-defense against an armed attack, actual or imminent;

(2) There is, however, no right to take military action in selfdefense against a threat that is not imminent;

(3) In determining whether an attack is imminent, the gravity of the threat and the means by which it would materialize in

115. See Foreign Secretary's statement, supra note 103, at para. 11.

116. President's State of the Union Address (Jan. 28, 2003), available at http://www.whitehouse.gov/news/releases/2003/01/20030128-19.html (last visited Mar. 3, 2003). 
violence are relevant considerations and mean that the concept of imminence will vary from case to case;

(4) The Security Council can authorize States to use pre-emptive military force against a threat to the peace in circumstances where an attack is not yet imminent;

(5) The scope for pre-emptive action under the collective security regime is therefore more extensive than under the right of self-defense;

(6) Neither the right of self-defense nor the collective security regime is confined to threats emanating from States. 
